\title{
INFÂNCIA EM WALTER BENJAMIN: DESCAMINHO DO PENSAR
}

Maria do Carmo Morales Pinheiro*

Resumo: Este ensaio problematiza certas características da infância que, histórica e filosoficamente, a colocam numa posição de menor prestígio por tratar-se de um lugar-tempo de confusão, erro e fragilidade, com o objetivo de reafirmar tal posição como potência de um outro modo de sentir e pensar o mundo e seus fenômenos sociais. Para isso, encontro em Walter Benjamin, que aborda a infância como signo de descontinuidade e de luta contra a morte a partir da instauração da experiência e da linguagem, um campo fértil para pensá-la como um desmétodo, ou, descaminho do pensar.

Palavras-chave: infância, pensamento, Walter Benjamin

\begin{abstract}
This essay problematizes certain characteristics of the childhood which, historically and philosophically, is put in a position of less prestigie, because it's a time-place of confusion, error and frailty; with the objective of reaffirming such position as potency of a different way of feeling and thinking the world and its social phenomena. For such, I find in Walter Benjamin, who approaches childhood as a sign of discontinuity and struggle against death by the instauration of experience and the language, a fertile field to think it as antimethod, or, deviation of though.
\end{abstract}

Key-words: childhood, thought, Walter Benjamin

A verdade é uma coberta que deixa os pés frios. Você a puxa, estica, jamais será suficiente. Nunca vai cobrir nenhum de nós. Desde que chorando entramos até que mortos partamos, só vai cobrir nosso rosto, enquanto choramos, gritamos (Todd, personagem do filme Sociedade dos poetas mortos, 1989).

Existem muitas coisas e fenômenos, como a infância, que na atualidade aparecem como termos gastos e exauridos pela saturação de sentidos até aqui acumulados e, portanto, difíceis de desmontar ou, mesmo, atualizar. Uma certa sensação de impotência se instala junto à empresa de pensar a infância, pois parece, realmente, que sobre ela tudo já foi pensado e dito. Contudo, o esgotamento diante de tantas respostas (científicas, religiosas, pedagógicas, mercadológicas etc) e os caminhos apontados na tentativa de definir a infância, a partir de descrições, catalogações e explicações, denunciam o quanto tais respostas acabam por aprisioná-la em certos moldes, e, como é sabido, todo molde é limitado/limitante.

Engenhosamente erguidas por diversas teorias e explicações razoáveis, quando não arrasoantes, e

* Doutora em Educação pela Universidade Metodista de Piracicaba (UNIMEP). Professora Adjunto IV na Licenciatura em Educação Física da Universidade Federal de Goiás/Regional Catalão (UFG/RC). E-mail: carmopin@gmail.com

\begin{tabular}{|l|l|l|l|l|l|l|}
\hline APRENDER - Cad. de Filosofia e Psic. da Educação & Vitória da Conquista & Ano XII & n. & p. & $95-$ & jan./jun.2018 \\
\hline
\end{tabular}


até mesmo por alguns imperativos, são muitas as verdades que entopem os poros de nossa pele e de nosso pensar e que tantas vezes nos lançam ao esquecimento da sua não-rara insuficiência para cobrir a inteireza do corpo e da existência, como lembra a epígrafe que abre este ensaio. Porém, apesar do vasto arsenal de conhecimentos existentes acerca da infância, talvez seja chegada a hora de dizer que, apesar de tantas descrições e prescrições, há um não-saber que sempre se renovará frente a ela. Que conviver com esse não-saber pode ser saudável para o pensamento (e para a ação); afinal, é preciso viver bem com as lacunas, sem temer os cobertores que esfriam os pés, e, que, não obstante, auxiliam a aquecer outras partes do corpo. Trata-se de aceitar a carência e os limites da própria capacidade humana de pensar e, principalmente, de atingir verdades finalistas.

O amontoado de conhecimentos causador de alguns sufocos leva a interrogar o tipo de pensamento que tornou aqueles possíveis: o modelo racional moderno, abstrato e cartesiano, que divorciou razão e sensibilidade (do corpo, da dor) e se aliou ao anseio da evidência, do cálculo e do domínio, e que, por estes motivos, se pretendeu totalitário. Tanto que fez da infância alvo de inúmeros controles para fixar, de uma vez por todas, o seu lugar e as suas questões em nossa sociedade; mas ela, sempre fugidia, insiste em livrar-se de coberturas e (en)cobrimentos asfixiadores de sua dinâmica, como muito bem ensina Walter Benjamin.

A fenda aberta por esse autor me instigou a perscrutar na infância uma possibilidade capaz de 'desarmar o pensamento', que carece da carne dela, de sua errância e flutuação, caso queira arriscar-se e lançar-se aos desafios postos pela vida como ela se nos apresenta. Talvez porque acerca da infância apenas seja possível ensaiar e/ou balbuciar análises, sem esquecer da sua eterna provisoriedade - e precariedade. Assim, o presente texto visa discutir algumas dimensões da experiência infantil como possíveis categorias epistemológicas presentes, a partir de certas pistas, nas reflexões de Walter Benjamin; pistas que levaram a vê-la e persegui-la como imagem de um desmétodo ${ }^{1}$, quer dizer, como um descaminho do pensar que pode ser fértil para a pesquisa social.

Nesse sentido, a infância não é, necessariamente, uma categoria epistemológica que estaria dada no interior do pensamento benjaminiano, mas, a partir de sua centelha, talvez, e, principalmente, potência de um pensar e de um conhecer que, entretanto, não estão à procura de uma verdade categórica, presumidamente apta a apacentar as dificuldades da vida, e, sim, de produção de sentidos a partir dos vacilos que os mobilizam. Essa potência aqui é tomada em sua ambiguidade produtiva; de um lado, como possibilidade, porvir, abertura ao que não se sabe, de outro, como força que arrasta e ativa a

\footnotetext{
$1 \mathrm{O}$ uso do prefixo DES junto à palavra método, que aponta negação ou involução, inspira-se na poesia de Manoel de Barros, que busca desmanchar e refazer palavras brincando com seus possíveis sentidos - e (des)sentidos. Nesse caso, desmétodo indica justamente a ausência de método, ou o seu desmanchamento enquanto caminho com pressupostos prédeterminados ao qual o pensamento precisaria se adaptar para fazer sua jornada. Desmétodo, então, sinaliza a inexistência de um itinerário seguro, para que o pensamento possa criar sua trajetória no próprio andar, cujo impulso mais vigoroso é dado pelas incertezas que o afligem.
} 
caótica do corpo do pensar para um encontro e um confronto com o real, quer dizer, com a vida. De qualquer forma e apesar do reconhecimento de que Benjamin não tem na infância uma categoria epistemológica explícita, em alguns momentos são feitas tentativas de aproximar aspectos do seu método de certas dimensões da infância.

As principais fontes de apoio dessa empreitada são os ensaios Infância em Berlim por volta de 1900, Rua de Mão Única e Imagens do pensamento, de Walter Benjamin (1995; 1984a; 1984b), escritos de Gagnebin (2005; 2001; 1999), nos quais ela debate a relação entre infância e pensamento, mímesis e expressão, a criança e o labirinto; de Matos (1997; 1993), que mostram como nosso autor se apropriou de e utilizou certos conceitos de Descartes e Kant. Assim, apresento algumas ideias no esforço de decifrar hieróglifos benjaminianos e, então, tecer a infância como descaminho do pensar.

Cabe ainda dizer que essa assertiva se relaciona umbilicalmente com a forma de escrita eleita para o presente estudo, a do ensaio. Se a infância, tal como afirmada por Benjamin, é condição humana sui generis que, via de regra, cai no esquecimento, de certo modo, ela é reabilitada na escrita ensaística. O ensaio, por ser desmétodo, sem regras nem anteparos de nenhuma ordem, experiência espiritual aberta e de tracejamento dos próprios passos, de dúvida permanente e de falta de segurança, remete diretamente às aparentes fragilidades da infância que, neste ponto de vista e, em particular, neste ensaio (assim como em Walter Benjamin), figuram como forças do pensamento e da escrita. Afinal, perguntase realmente quando não se sabe, quando algo incomoda e provoca perplexidade, quando as incertezas pulsam de modo a alçar quem as tem em alguma direção.

Para Benjamin (1984a), a infância é uma categoria profundamente histórica: marcada pela e marcante da história. Nisso, sua concepção já se diferencia da perspectiva filosófica acima citada. Para esse autor, a infância é tensão permanente: busca por afirmação que não se faz sem luta, sofrimento, angústia e, ao mesmo tempo, com a simples alegria de existir. Mas, mesmo que relativize aquelas características universais, ele as reverte em favor da infância, conferindo-lhes outras conotações que podem ser apontadas como faces e forças do pensar (desmétodo), pois nosso autor concebe a infância como essencial para elaborar a produção da vida, da história e do conhecimento. "Se Descartes concebe [a infância] como um momento patológico do conhecimento - época na qual a alma está tão misturada ao corpo para fins de sobrevivência que a impossibilita de pensar -, para Benjamin é um modo de existência crítico e epistemológico, crítico em sentido epistemológico” (MATOS, 1997, p. 39, interpolações nossas).

A infância é um modo de existência crítico porque põe à prova exatamente aquelas incapacidades 
da criança que, na sua trajetória tece um caminho constituído por dificuldades e conflitos os mais diversos; que, principalmente, se move por uma vontade de 'querer', de expandir suas possibilidades rumo ao desconhecido, nele escavando brechas e fazendo das incertezas suas aliadas mais fiéis. Apesar de buscar segurança nas nomeações - mesmo que provisórias - disponibilizadas pela linguagem, bem como em um saber que a ela vem atrelado, nem por isto a criança deixa de desconfiar do que é considerado óbvio, postura de valor inestimável do ponto de vista epistêmico.

Ver na infância um "modo de existência crítico em sentido epistemológico" sugere a configuração de atos de exame/avaliação da realidade muitas vezes instauradores de crises que forçam a criança a vencer as dificuldades interpostas no curso das suas investigações - enfim, os medos do inseguro. Sugere ainda uma maneira de desbravar o enigmático com determinado vigor, quiçá imputável somente às crianças, posto que as impele a dobrarem-se sobre os objetos de sua curiosidade e afastarem-se com o mesmo ímpeto, movimento implicado em riscos e em que são garimpados (des)entendimentos, os quais, sobretudo, alertam e despertam o pensar. Trata-se de processos que indiciam esforços da criança para se apropriar do mundo e reinventá-lo, (re)nomeá-lo, para criar seus modos de existência no lugar e na cultura de que é parte.

Além disso, há dor encarniçada nos processos de aprendizagem, seja porque o acesso ao saber muitas vezes é como adentrar a escuridão de grutas que se deseja explorar, cujas sinuosas estalactites confundem, causam assombro e nunca oferecem segurança com relação ao caminho de volta, seja porque o enfrentamento ao saber pode produzir dor quando se compreende sua insuficiência para tornar o real passível de inteligibilidade. Talvez, também, porque sempre que nos apossamos de alguma explicação mais sistemática das coisas e da vida, estas nos parecem perder sua magia inicial; ou, simplesmente, porque o contato com a dor, isto é, com as agruras de algumas situações, força a que se aprenda com estas experiências - como é o caso do aforismo "A febre", da Infância berlinense, em que Walter Benjamin relata que, com a doença, professora tenaz, aprendeu o tempo da espera, o cansaço de ser medido e o desalento de (re)lembrá-la (registrada nas horas perdidas de aula). A invasora invisível se despedia sorrateiramente como houvera chegado, mas, ao passar por aquele corpo, deixara suas marcas.

No final das contas, é preciso admitir que, de certa forma, pensar dói, porque crescer dói; fazer do pensamento um companheiro permanente na busca e/ou na produção de sentidos possíveis para o ‘estar no mundo' pode ser bastante difícil e dolorido. Ao relembrar e reelaborar sua infância berlinense, Benjamin destaca relatos instigantes, pois crivados de (des)gostos, como é o caso de sua relação com a instituição de ensino: seus atrasos denunciados pelo relógio da escola, que, para ele, encarcerava o tempo; os livros tradicionais incapazes de dizer algo à criança ávida por saber, mas, também, por vida; as manhãs de inverno nas quais, sem a mínima vontade, devia levantar-se para cumprir as obrigações estudantis. Leiamos com alguma parcimônia o aforismo "Manhã de inverno": 
[...] apenas a voz da babá perturbava a prática por meio da qual a manhã de inverno costumava me unir aos objetos em meu quarto. A persiana ainda não fora erguida quando já pela primeira vez eu afastava a tranca da portinhola a fim de seguir o rasto da maçã no forno. [...] Era a viagem através do escuro país do calor do fogão, da qual a maçã havia recolhido o aroma de todas as coisas que o dia pusera a minha disposição. E por isso não estranhava que, ao aquecer as mãos em sua superfície brilhante, sempre me constrangesse a dúvida de mordê-la ou não. Sentia que o fugaz conhecimento que me aportava em seu aroma podia me escapar com toda a facilidade ao passar por minha língua. Conhecimento que, às vezes, me instilava tanta coragem que, no caminho da escola, me servia ainda de consolo. Quando lá chegava, porém, no contato com meu banco, toda aquela fadiga, que parecia ter se dissipado, voltava decuplicada. E com ela o desejo de poder dormir até dizer basta. Devo tê-lo experimentado milhares de vezes, e, mais tarde, de fato, ele se concretizou. Custou-me, porém, muito tempo para nisto reconhecer que fora sempre vã a esperança que eu nutrira de ter colocação e sustento garantidos (BENJAMIN, 1995, p. 84-85).

Ao pintar no papel as memórias da infância burguesa que vivera no início do século XX, o adulto Benjamin mapeia vestígios de sua, sempre atual, inadaptação, acompanhada das dores que a fizeram emergir. Ao reconstituir o funcionamento daquele mundo pedagógico, espécie de ensaio para a vida adulta, nosso autor desfia as sensações mais perturbadoras - tantas vezes suportadas apenas pela presença de outras, alegres e viçosas -, que, mesmo sem saber, já indiciavam sua incapacidade para ter sucesso econômico ${ }^{2}$. A indisciplina do pensamento (e dos desejos) de Benjamin se manifestava fortemente em sua experiência infantil, em face da incompetência para fingir-se disciplinado e conformado com aquela ordem da qual desejava escapar. Isso aponta uma fertilidade incontestável da flutuação do pensar, de sua indisciplina, bem como da escuta do corpo: porque, muitas vezes, são as dores que excitam e incitam o pensamento, insistindo em fustigá-lo. E é essa experiência crítica e epistemológica que aqui interessa, pois faz da precariedade um catalisador que impulsiona a urdidura de rotas, independentemente de suas desembocaduras.

É nesse andar, desorientado e vacilante, à procura de sentidos e significados que lhe permitam 'ser' e afirmar sua existência, que a criança angaria conquistas, acumula derrotas e, sobretudo, experimenta, sem nunca parar. A vontade de pertencer ao mundo em sua volta lhe provoca constantemente, algo realizado desordenada e confusamente. Desse ponto de vista, a infância se constitui como lugar cuja geografia pode ser metaforizada pelo labirinto - imagem imanente ao pensamento benjaminiano -, construção de caminhos tortuosos que se enredam e complicam a aventura de neles trafegar; lugar cheio de fechamentos e aberturas intercomunicáveis em que as setas não estão dadas e do qual é preciso inventar os trajetos e as saídas.

A esse respeito, no conto "Rua Steglitz esquina com a Guenthin", da Infância berlinense, nosso

\footnotetext{
${ }^{2}$ Vários estudiosos da obra de Walter Benjamin apontam essa característica nele: a de ser um sujeito sem muito talento para sustentar a si e a sua família. Por esse motivo e considerando outros aspectos, como seus problemas amorosos, sua frustrada tentativa de seguir uma carreira na universidade e seu suicídio em virtude da perseguição nazista, Gagnebin (1982) o nomeia de "fracasso exemplar". Afinal, apesar de sua envergadura como pensador, em vida, não logrou esse reconhecimento, nem tampouco sucesso em sua vida pessoal.
} 
autor fala da casa das tias como labirintos explorados pela criança, cujas andanças lhe proporcionaram descobrir que se entra em alguns lugares, mas não em outros; que há cômodos em que se acendem muitas luzes (grandes salões), enquanto em outros, se apagam ou mantém-se turvas (vestíbulos dos empregados); que se abrem algumas portas, mas não outras. É de um emaranhado de proibições e permissões ofertadas pelo esquadrinhamento do espaço da casa que se retiram aprendizados do mundo social e de sua operacionalidade, que, por sua vez, inclinam a criança a preferir os lugares de passagem e as pessoas desimportantes.

Infância como labirinto é lugar de investigação, escavação, garimpagem, enfim, de encontros inesperados; território no qual a criança perde-se, caminha à deriva, (re)encontra-se e retorna para casa sempre um "outro', o que faz da experiência infantil algo irrepetível. Pelos labirintos da infância, a criança é arquiteta de si e do mundo que se ergue sob seus pés, principalmente a partir de suas possibilidades (quiçá, impossibilidades), desejos e escolhas - que configuram nós a ser desatados ou afrouxados, verdadeiros pontos críticos -, para as quais as lacunas podem ser muito bem-vindas.

Tradutor italiano de Benjamin e na sua esteira, Agamben (2005) afirma que é justamente a condição de ser in-fans no começo de nossas vidas que proporciona a instauração de uma experiência da própria linguagem. Nas palavras de Agamben (2005), a infância é o hiato (intervalo, interstício) entre voz e discurso, entre a experiência e a linguagem que nos tornam humanos, o que aponta, assim o entendo, para uma espécie de 'negatividade' essencial que de alguma forma em nós sobrevive e em muitas oportunidades, mesmo sufocada, grita; porque a in-fância não é algo que apenas antecede a linguagem e cessa com sua fundação, mas com ela coexiste. Tal intervalo é o que proporciona a introdução de uma descontinuidade ou diferença na cultura e na história, pois se não houvesse este istmo entre língua e discurso, experiência e fala, não existiria infância, conhecimento e/ou história.

O prefixo in, relativo ao que não se tem ou que não está dado à priori, e, por isto precisa ser construído-produzido, torna-se essencial ao pensamento e também à pesquisa, enfim, à produção do conhecimento. A descontinuidade ou obliquidade introduzida pela infância indica uma tensão permanente entre a tradição-cultura e a criação-ruptura, constituindo-a como um desvio, tal como o método benjaminiano exposto na sua introdução à Origem do drama barroco alemão, e aqui me arrisco a fazer uma primeira aproximação entre aquele e a infância. As características que remetem à incerteza diante do mundo que se quer e precisa experimentar, compreender, apreender, conquistar, enfim, pelo qual se deseja caminhar, fazem parte do pensamento humano para Walter Benjamin.

\footnotetext{
${ }^{3}$ Gagnebin (1999) afirma que a identidade desenhada na Infância Berlinense é irredutível da alteridade que a compõe, isto é, trata-se de uma identidade que busca no perder-se de si para reencontrar-se outro, a fonte da constituição infantil - e humana. Desse modo, na rememoração benjaminiana não há nenhuma nostalgia de uma suposta felicidade da infância, mas um reencontro com as vicissitudes históricas que a compuseram, numa jornada em que a perda de si é essencial à compreensão dos lastros histórico-sociais dessa conjunção-disjunção.
} 
Benjamin não ressalta a ingenuidade ou a inocência infantis, mas, sim, a inabilidade, a desorientação, a falta de desenvoltura das crianças em oposição à "segurança" dos adultos. Mas essa incapacidade infantil é preciosa: (...) porque contém a experiência preciosa e essencial ao homem do seu desajustamento em relação ao mundo, da sua insegurança primeira, enfim, da sua não-soberania (GAGNEBIN, 2005, p. 180).

À linearidade do método cartesiano, em busca do pensamento puro, lógico-matemático, Benjamin prefere o desvio, a desorientação e a assunção da impossibilidade de controle humano, seja sobre a natureza ou sobre seus pares: "Método é caminho indireto, é desvio. (...) Incansável, o pensamento começa sempre de novo, e volta sempre, minuciosamente, às próprias coisas. Esse fôlego infatigável é a mais autêntica forma de ser da contemplação” (BENJAMIN, 1984b, p. 50). Para esse autor, a verdade possui um ser indefinível, motivo pelo qual o pensamento precisa fazer malabarismos para apenas se aproximar dela, começando sempre novamente, pois, neste caso, "a apresentação da verdade é simplesmente ensaiada, exercitada" (MACHADO, 2004, p. 49). Tomar o método (ou o pensar) como desvio é compreendê-lo como atalho, corte, não-linearidade, fuga, mas também reencontro dos objetos investigados, num processo que não supõe o domínio, mas o acolhimento característico da contemplação, cujo fito admirado é lançado em múltiplas camadas de significação, infinitamente. Para isso, nosso desajustamento é fundamental, porque permite a obtusidade de nosso olhar frente a um mundo também obtuso; proporciona encarar o caos com a anormalidade que ele solicita. Além disso, na perspectiva aqui em debate, a própria infância é desvio, pois, apesar do seu necessário encontro com a tradição, enfim, com a cultura, há sempre eclosão do novo, produção de itinerários diversos feitos sob o signo da criação. Assim, o desvio é sinuosidade, caminho alternativo, negação do sempre-igual, para que se possa ver, sempre e de novo, de um jeito diferente.

Nesse sentido, ao falar sobre Benjamin, Gagnebin (2001, p.354) afirma que “[...] a defesa de um pensamento disruptivo, descontínuo, arriscado, errante, e vagante/vagabundo também é a crítica ao ideal de um rigor cartesiano interpretado como a tentativa de dominar uma realidade conflitiva, que não pode ser simplesmente sanada pelo desejo de coerência".

Não seriam estas algumas das características da infância apontadas anteriormente? A inabilidade, as incertezas/inseguranças, a errância, o risco, a descontinuidade marcada pela confusão são elementos presentes numa certa imagem de infância, criticados por tornarem-na frágil e a mercê das paixões, mas que, para Benjamin, são características do pensamento humano, devendo ser aproveitadas para que se capte e sinta melhor o real; para que o pensamento possa reinventá-lo/reinventar-se e, quiçá, vitalizá-lo/vitalizar-se. Esse é um dos motivos pelo qual penso que a infância pode ser considerada uma categoria epistemológica no pensamento de Walter Benjamin, que parece tomá-la como protótipo de como olhar para os objetos de conhecimento, sem que se queira dominá-los permanentemente, sendo tão incoerentes quanto eles o são. Se o mundo é incoerente, é assim que o pesquisador precisa olhá-lo: com uma visão atravessada, estranhada, como o faz a criança ante ao mundo, às coisas, ao desconhecido, na tentativa de atribuir-lhe algum sentido; no esforço de traçar uma 
perspectiva que permita a ela fitar/enfrentar a vida.

Benjamin abre mão da ordem cartesiana, geométrica e linear, porque entende não ser possível, por esta via, dar conta de uma realidade tão incongruente como a do mundo moderno. Matos (1993), afirma a pertinência das ideias de incoerência e incongruência presentes no método em Benjamin, já que o mundo assim é: a geometria não exclui a melancolia porque o objeto que escapa à consciência desperta, "revela a impotência da razão abstrata e calculadora em remover o sentimento da incoerência da vida" (MATOS, 1993, p.168). Para nosso autor, inclusive as palavras são insuficientes para expressar a realidade, posto que esta possui certas dimensões inefáveis. O que pensar, então, de palavras limitadas a expressar uma lógica matemática? Palavras crivadas de um poder mórbido que repetidas vezes lança seu pútrido odor sobre as coisas?

Ao problematizar a própria linguagem, mais uma vez, aparece a infância como possibilidade para se pensar o pensamento:

As imagens da infância evocadas por Benjamin tentam pensar aquilo que, profundamente, jaz neste prefixo in - da palavra infância. O que significa para $\mathrm{O}$ pensamento humano essa ausência originária e universal de linguagem, de palavras, de razão, esse antes do logos que não é nem silêncio inefável, nem mutismo consciente, mas desnudamento e miséria no limiar da existência humana? Nem domínio do pecado nem jardim do paraíso, a infância habita muito mais, como seu limite interior e fundador, nossa linguagem e nossa razão humanas. Ela é o signo sempre presente de que a humanidade não repousa somente sobre a sua força e poder, mas também, de maneira mais secreta, mas tão essencial, sobre suas falhas e suas fraquezas, sobre esse vazio que nossas palavras não deveriam encobrir, mas, muito mais, acolher (GAGNEBIN, 2005, p. 180-181, grifos da autora).

A infância que persiste e faz morada na linguagem e no pensamento. O que ver neste desnudamento senão um 'abrir-se' diante daquilo que se deseja enfrentar e conhecer? Como reagir (agir, pensar) frente aos objetos que ofertam apenas pistas ao pensamento? Parece que a anterioridade ao logos apela à retomada do corpo na excursão que leva à leitura dos sinais emitidos pelas coisas e pela vida; sinais do e no corpo que, como pressentimentos a respeito do mundo, materializam forças e modos de conceber e de conhecer. Desse prisma, o pensamento não sabe aonde vai chegar - não pretende confirmar hipóteses -, pois prefere perambular, e é justamente por meio desta deriva que se torna apto a captar a virtualidade, a possibilidade, o vir-a-ser, nos fragmentos efêmera e fugidiamente visualizados. Por conta desse desprendimento, o olhar se revela renovadamente inaugural, como se ele tudo observasse pela primeira vez, estado que o despe da demanda de uma evidência tantas vezes cega. Ao auscultar as dicas do corpo, o desejo benjaminiano de vidência (MATOS, 1990) iça o olhar como fulguração. É um olhar desprevenido que apreende o eterno do instante, do agora, da surpresa, como uma chance de jogo, de pensamento e de ação. Infância no olhar, no corpo, no pensamento e na linguagem. Pensamento que olha. Olhar que pensa. Pensamento com corpo. Corpo pensante. Linguagem que vê, sente e diz (mas também cala), porque abriga a carne, o vinho e a febre da infância. 
Quando o vazio deixado pelas palavras não importuna. A ausência de fala e de razão que marca a ideia de incompletude, a lembrar o que não é passível de racionalização e mesmo de linguagem, é um elemento que parece apontar para dimensões da infância comuns ao pensamento. Afinal, esse, tanto quanto o próprio mundo, é caos, desordem, em que as palavras e a razão põem uma ordem sempre fugaz, nunca definitiva, como bem lembra Manoel de Barros (2006), ao reivindicar que a linguagem não reduza ou mate as coisas mesmas, já que nomeá-las é apenas parte de um processo muito complexo e não limitado a ela, posto que sua tarefa é dar-lhes vida:

O rio que fazia uma volta atrás de nossa casa era a imagem de um vidro mole que fazia uma volta atrás de casa.

Passou um homem depois e disse: Essa volta que o rio faz por trás de sua casa se chama enseada.

Não era mais a imagem de uma cobra de vidro que fazia uma volta atrás de casa.

Era uma enseada.

Acho que o nome empobreceu a imagem (BARROS, 2006, p. 25).

Esse fragmento poético se aproxima muito do modo como Benjamin, crítico literário, pensava o próprio pensamento, necessariamente mediado por imagens que lhe confeririam movimento e vida. Inclusive seu conceito de alegoria evoca a presença da imagem como elemento fundamental ao pensar, ou mesmo sua grande obra Passagens, em que toma as passagens parisienses como rastros do inventário da ascensão e da queda do projeto burguês de sociedade, já que indicam tanto o culto à mercadoria quanto lembram as mazelas criadas por este mesmo culto moderno: sociedade de aço e vidro, esfacelada pelas manchas da pobreza e da guerra geradas em meio a tanta riqueza. $\mathrm{Na}$ imediatez da presença sensível da mercadoria, vista na arquitetura moderna francesa, nosso autor buscou contemplar a produção de desejos capitalistas, o fetiche e a magia alienante das luzes da cidade (TIEDEMANN, 2006).

Walter Benjamin pensa por imagens, o que Tiedemann (2006) chama de pensamento fisionômico, uma espécie de corretivo mimético e perceptível do real. A ideia de iluminação profana em Benjamin, ligada às suas experiências com os sonhos e as drogas, nas quais buscava perceber uma ligação mimética e corpórea com as coisas, carrega a intenção de formular uma teoria da experiência relacionada à faculdade mimética (TIEDEMANN, 2006). Nessa direção, a própria linguagem precisaria restituir uma ligação sensível com as coisas, deixando de ser apenas comunicativa e abstrata - mais exata, porém, empobrecedora das imagens, como lembra a poesia de Manoel de Barros -, para tornarse, também, mimética.

Ora, a inefabilidade do real, que nem todas as palavras do mundo são capazes de cobrir, junto da experiência investigativa, que, para Benjamin, visa acessar diversas camadas de sentido (GAGNEBIN, 1982; MACHADO, 2004) que só podem ser apuradas por um processo contemplativo, reabilita a mímesis e o próprio corpo no refinamento do saber, buscado por um pensar mais sensível, estético, ao que parece. E não são as crianças boas entendedoras do fazer mimético e da produção de 
imagens que possam dar vida ao que querem dizer?

Me parece que as dimensões da infância tratadas até o momento podem orientar o olhar do pesquisador para seu objeto. "O mundo em que a criança vive suas relações com o outro é um claroescuro de verdade e engano. Neste mundo a verdade não é dada, não está acabada, impressa de forma imutável na consciência humana; a verdade é algo que se faz constantemente nas relações sociais e por meio delas" (JOBIM e SOUZA \& PEREIRA, 2005, p. 36).

Pensar um mundo em que verdade e engano, claro e escuro se misturam, como que a nos dizer que a vida é feita de luz e sombras, certamente aponta para uma via alternativa, um 'desvio' que atinge frontalmente os princípios de um método que busca clareza e distinção. Ver o mundo como um misto de ruído e silêncio, luz e escuridão, que se constituem mutuamente e não são decantáveis, pois o complexo também está no simples e vice-versa, parece mesmo mudar a perspectiva de quem se aventura à pesquisa, posto que a verdade passa a ser construto incessante.

O não-dito - o silêncio, o escuro - é já um dito, ou interstício para o sentido, ou, ainda, ocasião para uma espécie de vibração; o indizível se diz de algum modo, pois uma criança pode não falar, a palavra que nomeia pode ainda inexistir, mas as sensações gestam (des)entendimentos expressos de alguma forma. E se há geração de sentido mesmo sem palavra, é porque há algo informe em curso, como uma espécie de elaboração balbuciante que tenta vir à luz; contudo, ainda que permaneça soterrada, nada assegura seu sepultamento irrevogável, senão sua suspensão momentânea. Nesse sentido, a própria infância se faz como o obscuro da linguagem (e do pensamento): a escuridão do semsentido que confere sentido, isto é, outro sentido, outra seta; ou, ainda, o que diz um outro que não ele mesmo, como a alegoria benjaminiana: "é aquilo que não se compreende o que faz sentido" (MATOS, 1990, p. 296), o que torna o jogo das luzes e das sombras ainda mais complexo e, quem sabe, erótico (?), brincalhão.

A obscuridade (o desconhecido) empurra para frente; afinal, o sem-sentido é oportunidade e porvir, está aberto. Assim, o pensar abstrato e descarnado é posto em xeque pela infância, capaz de despojar a evidência de seus poderes. E a verdade, que sempre joga com os espectros de luz (e de sua ausência), sejam eles incidentes, difusos ou refratários, também se achega à infância:

[...] a verdade (tal como uma criança) se recusa, diante da objetiva da escrita, quando nos acocoramos sob o pano preto, a olhar quieta e amistosamente. É bruscamente, como com um golpe, que ela quer ser afugentada de seu mergulho em si mesma e despertada num susto, seja por tumulto, seja por música, seja por gritos de socorro (BENJAMIN, 1995, p. 60).

Ainda que muito pouco ou quase nada cubra, a verdade também prefere o imprevisto à cristalização, o fito multicor ao monocromático, a efervescência à comodidade; ela deseja escapar do que a mumifica e retém seus olhos estalados de horror. Todavia, o que pode pô-la a correr de si, também pode encontrá-la, como no pique-esconde das crianças: na iminência da aproximação de quem 
a procura, um lance de espanto que a encurrale; o assalto que a paralise por apenas um instante pela escrita capaz de bordá-la no papel (ou na tela!): somente por um breve instante. Porque o devir é o sagrado que nelas habita: na infância e na verdade.

Matos (1993) afirma que, para Benjamin, “o homem que conhece é uma espécie de consciência delirante" (MATOS, 1993, p.135), exatamente como se permite ficar a criança quando brinca, ensaia suas descobertas, constitui seus conhecimentos do mundo a partir dos seus objetos, mas também de seus destroços e escombros. Aqui, um parêntese. O delírio geralmente é definido como um estado em que se fala coisas não condizentes com o real, estado de exaltação, alucinação, entusiasmo excessivo, frenesi, confusão, loucura, desorientação, ilusão (HOUAISS, 2007), enfim, de perturbação, de permissão à libido e abertura ao caos. Parece-me que este estado, em que o real aparece como algo fluído, passível de ressignificação, é aquele em que a aparência das coisas é escarafunchada, numa tentativa de reconstituir o real com outros sentidos ou de atribuir-lhe outros sentidos. E mais, o estado de perturbação pode muito bem dizer respeito à gestação e ao nascimento de algo prestes a vir à tona, mas não se sabe muito bem de que modo; pode referir-se às intensidades que fazem brotar algo, mesmo sem que se saiba o quê e nem como brotará, o que nos coloca em estado confuso, de desorientação e perturbação, pois algo está mexido.

Nessa direção, a consciência delirante aponta um estado de consciência que não se apoia numa razão extremada, que visa o aniquilamento dos sentidos e da dimensão intensiva do corpo, pois estes são acolhidos e postos em movimento. Assim, o brinquedo infantil suscita uma procura intensa, delirante e corpórea, mesmo que feita mediadamente pelos signos, pela linguagem, portanto, por uma racionalidade em constituição e constitutiva da experiência lúdica - culturalmente situada. Nesse sentido, a linguagem, sempre limitada para nomear e caracterizar o real, se torna objeto de uma deliciosa brincadeira para Manoel de Barros, quando invertida, numa palavra, 'delirante':

\footnotetext{
No descomeço era o verbo.

Só depois é que veio o delírio do verbo.

O delírio do verbo estava no começo, lá onde a criança diz: Eu escuto a cor dos passarinhos.

A criança não sabe que o verbo escutar não funciona para cor, mas para som.

Então se a criança muda a função de um verbo, ele delira.

E pois.

Em poesia que é voz de poeta, que é a voz de fazer nascimentos

O verbo tem que pegar delírio. (BARROS, 2006, p.15, grifos do autor).
}

Nesse poema lê-se que a princípio a palavra delira justamente pela boca de uma criança, que, antes de racionalizar, experimenta e sente o mundo, as coisas e as próprias palavras - ou, no começo, a 
potência de seus sons. Enfim, trata-se da intensidade do que pode ser vivido, no caso, o dito e/ou o escutado. Começa-se pelo delírio: só ele é capaz de tirar dos lugares bem arranjados. Desse ponto de vista, a ordenação do mundo proporcionada pelo verbo e pela palavra, vem sempre depois da sensação, da experiência sentida na pele.

Toda e qualquer experimentação de criança pode fazer as coisas delirarem, sair dos lugares funcionais e previstos para assumir outros, pois seus caminhos são tecidos num movimento ziguezagueante que se presta a desfazer e refazer coisas, sons, palavras, signos, linguagem e mesmo a própria cultura. Assim como na poesia, de modo análogo a uma criança, é preciso desfazer/desmanchar a linguagem e recompô-la em outros termos, brincando com suas possibilidades para que ela possa delirar. Também destruir o objeto do conhecimento, despedaçá-lo para desdobrar camadas de sentido e depois reconstruí-lo são movimentos fundamentais do método em Walter Benjamin, motivo pelo qual me proponho a ver a produção do conhecimento também como brincadeira, de destruição e restituição. Essa dimensão filosófica - e poética - da experiência da infância para o autor é pontuada, por exemplo, no pequeno texto denominado 'Canteiro de Obras':

[...] as crianças são especialmente inclinadas a buscarem todo local de trabalho onde a atuação sobre as coisas se dê de maneira visível. Elas sentem-se irresistivelmente atraídas pelos destroços que surgem da construção, do trabalho no jardim ou em casa, da atividade do alfaiate ou do marceneiro. Nestes restos que sobram elas reconhecem o rosto que o mundo das coisas volta exatamente para elas, e só para elas. Nesses restos elas estão menos empenhadas em imitar as obras dos adultos do que em estabelecer entre os mais diferentes materiais, através daquilo que criam em suas brincadeiras, uma nova e incoerente relação (BENJAMIN, 1995, p. 77-8).

Os restos do mundo adulto são matéria-prima para as brincadeiras infantis, espaço onde são ressignificados e ganham vida especial, pois transformados em outros objetos, pessoas, papéis. Ao apropriar-se de certas espécies de materiais e conferir-lhes outros sentidos, a criança está destruindo-as e colocando outras 'significações' em seu lugar, num movimento em que, mais tarde estes objetos serão recompostos. Outro elemento ressaltado pelo autor é o da criação que ocorre a partir do estabelecimento de uma nova e incoerente relação entre os destroços que permitem a brincadeira, o que lembra as 'Meditações sobre um cavalinho de pau' de Gombrich (1999), para quem este objeto, assim como a arte, não representa nem imita/retrata o real, mas o substitui na instauração de uma outra realidade. Para Benjamin, é isso que faz o pensador com seus objetos de conhecimento: os destrói, para em seguida e a partir de outras relações possíveis, reconstituí-lo com outra percepção/compreensão, alavancada num processo que é criador e muitas vezes condensa elementos incongruentes. A cada aproximação dos objetos/artefatos, dos destroços ou das coisas da natureza, em suas brincadeiras, as crianças constituem um mundo próprio (dentro de um maior) capaz de alavancar sua compreensão do mundo - e me arrisco a dizer que o método em Benjamin é proporcionado por um movimento 
bastante similar a esse.

Para ajudar essa defesa, recorro à Gagnebin (1992) que afirma haver uma experiência de destruição e restituição que marca todo o pensamento de Benjamin, até mesmo quando descreve uma brincadeira que costumava fazer quando criança em seus armários, ao desmanchar o bolso formado pela dobradura de suas meias. Ele inclusive tem um texto denominado "O caráter destrutivo", no qual ensaia que somente a destruição metódica reduz o mundo a entulho que pode abrir caminho ao novo. Wohlfarth (1997) afirma que o caráter destrutivo é uma força rasgante que não ocupa espaços e nem investe pessoas, somente produz tensão e instabilidade, como o próprio pensamento benjaminiano, que não deixou intactas suas referências (teologia judaica e materialismo dialético), mas fez emergir delas o novo. Também Machado (2004) chama atenção para o processo de destruição do objeto do saber que se dá na contemplação proposta por Benjamin como parte do método que ele empreende para pensar o drama barroco alemão. O papel da crítica é tornar seu objeto fragmento, para que a totalidade da obra possa emergir como mosaico, de elementos desiguais e isolados, no qual se mantém a singularidade e a verdade é exercitada: “[...] o conteúdo material da obra precisa consumir-se como a madeira que se torna cinza, para que seu conteúdo de verdade venha à luz como chama” (MACHADO, 2004, p. 61).

Além disso, me parece que a ideia de fragmento em Benjamin também diz respeito às mais ínfimas coisas, essenciais para inventariar certas práticas e nelas encontrar o espírito da vida moderna e burguesa. Nessa direção e com base em reportagem sobre os catadores de lixo das grandes cidades brasileiras, exibida pelo Globo Repórter, em 01.09.2006, não pude deixar de perceber certas relações entre a criança, tal como vista por Benjamin, o coletor de lixo e o pesquisador. Na referida reportagem, o foco estava na montagem de verdadeiros 'relicários' por parte dos catadores, que os fazem com as sobras, os restos do mundo. Garrafas pet, papelões, latas são relíquias que aos poucos entram em novas composições. Justamente o inútil, imprestável, que não serve mais para uns, é coletado, cuidado, tratado, transformado, reorientado e ressignificado pelas mãos do catador de lixo, que recicla, confere novas formas, enfim, reelabora, dá vida e reencanta o aparentemente inócuo, morto e sem valor, assim como faz a criança ao brincar com os restos do mundo. E não seria exatamente esse um dos papéis do pesquisador para Benjamin? Pensar a partir das sobras e do que parece inútil, improdutivo, montando relicários? Não é isso que o próprio Benjamin faz ao voltar-se para coisas consideradas pequenas e irrelevantes como a moda, colecionadores, brinquedos, jogos e prostituição? A esse respeito, Seligmann-Silva (2008) usa o termo historiador-catador, cujo papel, na concepção benjaminiana, é o de colecionar ruínas (os documentos de cultura) e salvar os detritos da história, visando à interrupção do seu curso, chamado de progresso, mas que não passa de destruição.

Um outro elemento também presente na brincadeira é a mímesis, que, para o autor destacado neste texto não ocorre por necessidade de identificação, mas para compreender o outro, o diferente, o não-idêntico. No brinquedo, a criança se desnuda de si para vestir-se do outro, e com isso apreende, se apropria dos objetos, das coisas, dos papéis que mimetizou. Mas ela sabe que brinca, e, como parte do 
seu empreendimento de conhecer e experimentar o mundo, volta a se desnudar dos objetos e papéis para distanciar-se deles novamente, dinâmica esta intrínseca ao seu processo investigativo. Benjamin (1995) elabora como isso ocorre no seguinte texto:

CRIANÇA ESCONDIDA. [...] Aqui ela está encerrada no mundo da matéria. Ele se torna descomunalmente claro para ela, chega-lhe perto sem fala. A criança que está atrás da cortina torna-se ela mesma em algo ondulante e branco, um fantasma. A mesa de refeições sob a qual ela se acocorou a faz tornar-se ídolo de madeira do templo onde as pernas entalhadas são as quatro colunas. E atrás de uma porta ela própria é a porta, está revestida dela como de pesada máscara e, como mago-sacerdote, enfeitiçará a todos os que entram sem pressentir nada. A nenhum preço ela pode ser achada. Quando ela faz caretas dizem-lhe que basta o relógio bater e ela terá de permanecer assim. O que há de verdadeiro nisso ela sabe no esconderijo. Quem a descobre pode fazê-la enrijecer como ídolo debaixo da mesa, entretecê-la para sempre como fantasma no pano da cortina, encantá-la pela vida inteira dentro da pesada porta. Por isso, com um grito alto ela faz partir o demônio que a transformaria assim, para que ninguém a visse, quando quem a encontra a pega - aliás, nem espera esse momento, antecipa-o com um grito de autolibertação. Por isso ela não se cansa do combate com o demônio. A casa, para isso, é arsenal de máscaras. Contudo, uma vez por ano, em lugares secretos, há presentes. A experiência mágica se torna ciência. A criança, como seu engenheiro, desenfeitiça a sombria casa paterna e procura ovos de Páscoa (BENJAMIN, 1995, p.39-40).

Ao estabelecer certas fronteiras que criam um mundo mágico e um momento místico, quasesecreto e particular, a criança mergulha nas coisas mesmas para poder senti-las e transformar-lhes o sentido e o significado, num processo intenso e agudo que a envolve na aura constituída pela brincadeira. Contudo, ela sabe dos limites de um espaço artificialmente inventado e, como que na tentativa de dirigir a situação, interrompe o processo quando se lhe aproxima o perigo, na figura de quem pode encontrá-la em seu esconderijo, o que aponta a presença de uma dimensão racional no processo. Esse 'entregar-se' infantil às coisas mesmas, mimetizando-as, faz parte de um percurso que contém, na outra ponta, a necessidade de que posteriormente ela se distancie da matéria, pois isto a auxilia a compreender melhor as próprias coisas. Aproximação e afastamento dos objetos, dois aspectos constitutivos de um mesmo processo, que é o da produção de conhecimento. Para Gagnebin (2001), esse movimento é indicativo de que:

Há uma dinâmica contínua entre experiência mimética e experimentação científica (...). É somente porque a criança se arrisca à imersão na matéria, à perda da própria identidade subjetiva que ela pode, igualmente, se transformar em detetive e engenheiro. A passagem da experiência mágico-mimética para a normalidade e a racionalidade cotidianas é assinalada pelo grito de autolibertação da criança que, por assim dizer, volta a si mesma no júbilo do salto fora do feitiço (GAGNEBIN, 2001, p.359-360).

A mímesis como impregnação do objeto, que é o outro e não o mesmo, porque diferente, pode ser encontrada em um dos contos de Benjamin ao rememorar/elaborar sua infância, em que destaca a 
relação criança-alimento/doce.

A DESPENSA - Na fresta deixada pela porta entreaberta do armário da despensa, minha mão penetrava tal qual um amante através da noite. Quando já se sentia ambientada naquela escuridão, ia apalpando o açúcar ou as amêndoas, as passas ou as frutas cristalizadas. E, do mesmo modo que o amante abraça sua amada antes de beijála, aquele tatear significava uma entrevista com as guloseimas antes que a boca saboreasse sua doçura. Com que lisonjas entregavam-se à minha o mel, os cachos de passas de Corinto e até o arroz! Com que paixão se fazia aquele encontro, uma vez que escapavam a colher! (BENJAMIN, 1995, p.87-8).

Aqui, mais uma vez a criança impregna-se pelo objeto, mistura-se a ele, respeitando-lhe a grandeza e diferença, agarra-lhe com o corpo e é por ele agarrada, pondo em movimento tanto seus sentidos experenciadores quanto um elemento racional, de esclarecimento (VAZ, 2006). Trata-se, me parece, de compreender um encontro bastante parecido com aquele entre pesquisador e objeto pesquisado. Para Benjamin, é preciso chegar-se às coisas mesmas e tentar sentir-lhes o gosto, o cheiro, o tato, enfim, educar os sentidos para ser flexível e poder contemplar os objetos a fim de melhor conhecê-los. Assim, a mímesis não contém apenas um elemento lúdico, mas também carrega uma dimensão que é racional e supõe linguagem, narração, elaboração, estas também constitutivas daquele e vice-versa.

Para Matos (1993), “enquanto o método cartesiano se aplica arbitrariamente a qualquer objeto, o indicado por Benjamin adere mimeticamente a um objeto particular de contemplação. Tal melancolia epistemológico-crítica vai de encontro ao saber consagrado" (MATOS, 1993, p.10-11). Assim, a contemplação como observação atenta, admirada, extasiada e silenciosa, pressupõe uma profunda reflexão sobre as coisas, o mundo, na tentativa de encontrar sua materialidade relacional, os sentidos e significados que lhe constituem, numa postura que engloba a necessária acolhida e o distanciamento dos objetos, dinâmica esta incessante e inconstante.

Ao pensar a infância como lugar do imprevisto, de experimentação mimética e de narração (experiência ou Erfahrung), como contemplação e desvio, Benjamin parece anunciar algumas das dimensões do seu método e da sua concepção de ciência. Tais imagens me remetem ao Equilibrista (ALMEIDA, 2003), personagem que constrói sua história sobre um fio, no limiar das possibilidades da vida, e, ao procurar a comodidade do chão, se desequilibra, para logo em seguida tornar a equilibrar-se e voltar a ver, porém e certamente, com outros olhos. A correlação entre equilíbrio e desequilíbrio presente no 'andar na corda bamba', como quem procura constituir errante e incessantemente seus lugares (nunca cabais) no mundo, me parece postura fundamental àqueles que se propõem a entendê-lo, explicá-lo, sistematizá-lo, sem, contudo, encerrá-lo. 
Benjamin dá um tratamento especial ao modo como a criança 'enxerga' o mundo, se coloca diante dele, ocupa certo lugar nele. Esse lugar, que também constitui suas maneiras de colocar-se nas relações humanas a fim de experimentá-las e elaborá-las, parece apontar para o olhar da criança como 'caçador', aquele que pretende capturar, agarrar, prender as coisas, colecioná-las. No ensaio Rua de Mão Única, há um pequeno texto em que esse entendimento é apresentado:

CRIANÇA DESORDEIRA. Cada pedra que ela encontra, cada flor colhida e cada borboleta capturada já é para ela princípio de uma coleção, e tudo que ela possui em geral, constitui para ela uma coleção única. Nela essa paixão mostra sua verdadeira face, o rigoroso olhar índio, que, nos antiquários, pesquisadores, bibliômanos, só continua ainda a arder turvado e maníaco. Mal entra na vida, ela é caçador. Caça os espíritos cujo rastro fareja nas coisas; entre espíritos e coisas ela gasta anos, nos quais seu campo de visão permanece livre de seres humanos. Para ela tudo se passa como em sonhos: ela não conhece nada de permanente; tudo lhe acontece, pensa ela, vai-lhe de encontro, atropela-a. Seus anos de nômade são horas na floresta do sonho. De lá ela arrasta a presa para casa, para limpá-la, fixá-la, desenfeitiçá-la. Suas gavetas têm de tornar-se casa de armas e zoológico, museu criminal e cripta. "Arrumar" significaria aniquilar uma construção cheia de castanhas espinhosas que são maças medievais, papéis de estanho que são um tesouro de prata, cubos de madeira que são ataúdes, cactos que são tótens e tostões de cobre que são escudos. No armário de roupas de casa da mãe, na biblioteca do pai, ali a criança já ajuda há muito tempo, quando no próprio distrito ainda é sempre o anfitrião inconstante, aguerrido. (BENJAMIN, 1984a, p.39).

Parece que Benjamin está nos falando de uma condição pertencente aos humanos, embora se refira especificamente à criança. Para ele, o colecionador que cata/coleta, visa apanhar signos; talvez seja isso o que, aos poucos e sem que se perceba, acaba se aplacando (ou se corrompendo) com o passar do tempo. O ‘rigoroso olhar índio’ sugere o nomadismo infantil; a criança é, em si, nômade, pois está sempre em processo, tal como o próprio pensamento: dinâmico e instável, sempre à espreita de outros desafios.

O olhar que arde, com intensidade, possui uma profunda severidade, é sério. E aqui é preciso considerar que a seriedade é, para Benjamin (1984a), a esfera mais adequada à criança. A caça aos espíritos remete à busca de sentidos, de significados, da aura (vibração) que compõe os objetos, as coisas, os lugares, para desmistificar o real: o que era mistério torna-se mais próximo, familiar, compreensível; embora permaneça envolto pelo encantamento que o originou, pois a criança o conserva em suas gavetas. A magia das coisas é desfeita pela pesquisa, pelo conhecer, porém não é esquecida e nem proscrita. Além do mais, como colecionadora, a existência da criança "é uma tensão dialética entre os polos da ordem e da desordem” (BENJAMIN, 1995, p. 228). Na casa ordenada, ela é sempre forasteira, estrangeira, porque andarilha; faz o caminho ao caminhar, experimentando e constituindo trajetos de maneira oblíqua, mas seu caos possui uma ordem, uma lógica interna, 
inventada por ela mesma, que expressa, sobretudo, estranhamento, que é produção de sentido.

Um conto interessante a respeito da visão da criança como estranhamento ao mundo é o da 'Coluna da Vitória', em que Benjamin revela seu olhar infantil sobre os desfiles cívicos de Berlim:

Quando eu era pequeno não se podia conceber um ano sem o dia de Sedan. Depois de Sedan só os desfiles sobejavam. Quando em 1902 Ohm Krüger, após a derrota na Guerra dos Bôeres, percorreu a Rua Tauentzien, também eu estava lá com minha governanta. Pois era inadmissível não admirar um senhor que, de cartola, se apoiava no coxim e que 'conduzira uma guerra'. Assim ele dizia. Mas aquilo me soava como faustoso [ostentatório] e baldo [inútil, sem proveito] de civilização; era como se o sujeito tivesse 'conduzido' um rinoceronte ou um dromedário e por isso tivesse se tornado famoso (BENJAMIN, 1995, p.77, interpolações nossas).

Aqui emerge o estranhamento infantil com relação às manifestações sociais mais importantes do mundo adulto. A declaração de que 'aquilo me soava como faustoso e baldo de civilização', nas palavras de Matos (1997), "significa a incompreensão do mundo (da história) dominante - o dos adultos - e é também a primeira defesa contra ele. A incompreensão não sendo neutra, o olhar da criança é o do materialista histórico" (MATOS, 1997, p. 84). Essa incompreensão, como a entendo, configura-se como momento de negação das explicações e/ou justificativas oficiais; uma espécie de desconfiança das aparências pretensamente claras e evidentes, portanto, negação do que é negado pelas/nas convenções sociais, pelos/nos bons modos. É como se a criança pressentisse, naquilo que é dissimulado ou olvidado, alguma porção sua; é como se ela visse subentendidos, na realidade, negações e escamoteamentos que não sabe explicar, mas que a fazem sentir a existência de outras verdades em estado de latência e que a qualquer momento podem eclodir. Nesse caso, trata-se de captar o que parece inacessível; e, por isto, o não-compreendido nos objetos revela-se como um outro modo de entender (GAGNEBIN, 1999).

O olhar infantil, incompreensivo diante do mundo, é aquele que tenta apreender as idiossincrasias, as singularidades e as contradições próprias dos fenômenos vivenciados. Benjamin (1995) nos convida a olhar para a criança como presença ardente e estranhamento ao mundo, resistência às imposições projetivas e, por isto mesmo, desvio. Todavia, não se trata de opor adulto e criança, pois eles compartilham uma mesma civilização e sistema social, cujas perversidades, contradições e paradoxos afetam a ambos. O caso é que não há como negar que a modernidade produziu um tipo de relação entre adultos e crianças que as infantilizou ${ }^{4}$, no sentido pejorativo do termo, e, com isto, tornou a assimetria de forças existente entre eles, maior ainda; é também para tensionar a sujeição que pode resultar desses processos que Benjamin lembra e elabora seus

\footnotetext{
${ }^{4}$ Aqui o sentido atribuído à palavra infantilizar - crianças ou quaisquer viventes - é o de subestimar as possibilidades e capacidades dos sujeitos de sentir e de pensar o mundo para nele se colocar, para nele assumir sua condição com dignidade, como destaca Ribeiro (1997), ao discutir a política infantilizadora dos poderes não democráticos, desde o despotismo até algumas modernas sociedades revolucionárias. Ainda que as crianças, por suas reais carências, precisem de proteção, isso não significa que devam ser tratadas e formadas a partir do ponto de vista da debilidade e da submissão, muito presente em diversas instituições modernas como a escola e a própria família. Se neste texto considera-se que a dependência e a desorientação também fazem parte da infância, de modo algum isso justifica idiotizá-la e/ou diminuí-la frente a modelos supostamente superiores de conduta humana, o que, justamente, concorre para depreciá-la, daí o uso de termos como 'infantilização' ou 'puerilização'.
} 
estranhamentos de criança.

Semelhante à rememoração de Benjamin sobre sua infância berlinense, é uma nota autobiográfica e poética de Antonin Artaud, ao se referir à estranheza e desconforto da criança que interroga a respeito dos sentidos de certas práticas da cultura/tradição, que se tornam, muitas vezes, perversas e opressoras; e por isto o questionamento do próprio sentido de ser e estar vivo:

Lembro-me, desde a idade de oito anos, e mesmo antes, de sempre ter perguntado: quem era eu, o que eu era e porque viver... O que significava ser e viver, qual era o sentido de se ver respirar e ter querido respirar a fim de me sentir viver e perceber se isso, de fato, me convinha, e em que me convinha. Eu me perguntava por que estava ali e o que significava estar ali [...] Eu me pergunto o que é Eu, não eu no meu corpo... mas em que pode consistir esse eu que se sente o que chamamos ser, ser um ser porque eu tenho um corpo? Sr. hábito, Sr. náusea, Sr. Mania, Sr. asco, Sr. câimbra, Sr. Vertigem, Sr. palmadas nas nádegas; Sr. palmadas anda junto com o Sr. insurgido, Sr. resposta, Sr. lágrima, Sr. sufocado numa alma escandalizada - para compor um eu de criança, uma consciência criancinha, a consciência de uma criancinha (ARTAUD apud LINS, 1999, p.80).

Num pensar sobre si arrancado das profundezas da pele, essa nota aponta para marcas e sulcos desenhados e cavados no corpo por meio da educação e que são muito comuns a todos nós. Desde a mais tenra infância, em nome da tradição, o corpo é levado a se sujeitar a uma série de rituais que o submetem; mas, no mesmo movimento e paradoxalmente, desafiam esse corpo a dar respostas e se rebelar, enfim, estranhar-se a partir do sufoco gerado neste processo. O corpo aturdido catalisa o pensamento, pode fazê-lo deslocar-se, movimentar-se em sentido diverso da opressão, a partir do seu estranhamento e inadequação - algo presente na criança.

Perceber o olhar infantil como caça/captura, que reconstrói, repõe, mas mantém o encanto, o estranhamento, a visão incomum, esquisita, inadaptada, me parece uma perspectiva valiosa para sentir, pensar e, quem sabe, balizar o fito do pesquisador, que precisa do estranhamento, do espanto e da surpresa do perscrutado, tal como Alice no País das Maravilhas: o seu não-saber para onde ir num mundo absolutamente estranho, mas, ao mesmo tempo, cheio de encantos e possibilidades. Tudo que ela pensava saber não servia naquele mundo, o qual possuía outra lógica e mexera tanto com ela, causando, inclusive, estranhamento de si. O prisma de Alice com relação àquele mundo 'esquisito' constitui-se em referência essencial para quem busca investigar a realidade: não como seus senhores, mas coadjuvantes que pretendem captar sua dinâmica, sua lógica interna, enfim, sua pulsação... simplesmente porque "as coisas não querem mais ser vistas por pessoas razoáveis: elas desejam ser olhadas de azul - que nem uma criança que você olha de ave” (BARROS, 2006, p.21). 
Este ensaio se propôs a ser um exercício reflexivo quanto às relações entre infância e pensamento, sem a intenção de simplificar os diferentes papéis assumidos pela criança ou pelo pesquisador em seus respectivos contextos e frente aos seus distintos desafios; nem tampouco 'reduzir' o método em Walter Benjamin, que possui outras tantas características e princípios não discutidos aqui. Do contrário, tentou-se respeitar ao máximo o seu pensamento. O esforço deu-se no sentido de posicionar algumas dimensões da infância repostas pelo autor, tais como as fraquezas e inseguranças, as angústias do incerto, a incompletude, a mímesis, a brincadeira, que supõem constante produção de sentidos; a incompreensão, o estranhamento, como elementos ou mesmo princípios, que ajudem a pensar um outro lugar, outro ponto de vista a partir do qual o pesquisador possa conceber o mundo, o conhecimento, suas limitações e seu próprio papel.

Entre a criança que brinca e o adulto que investiga, há diferenças qualitativas, sem dúvida, pois se trata de diferentes momentos e níveis de elaboração em distintos patamares da experiência humana. No entanto, quando me proponho a ver a produção do conhecimento como brincadeira, é no sentido de considerar a riqueza que possui sua dimensão filosófica e formativa para o pensamento humano e o próprio saber, como sugere Gagnebin (2005). Desse modo, ter a infância como um pressuposto do pensar soa como uma possibilidade interessante, porque dispare, fora de prumo e arriscada para aqueles que, ao abrigá-la, nem por isto estariam menos investidos do necessário rigor acadêmico, mas que, ao deixar-se envolver pelo real, como quem dança ou brinca, buscam dar-lhe sentidos que tentam manter e recriar o seu pulsar sempre inesgotável.

\section{Referências}

ALMEIDA, F. L. de. O Equilibrista. 11. ed. São Paulo: Ática, 2003.

AGAMBEN, G. Infância e História. Belo Horizonte: Editora UFMG, 2005.

ARIÈS, P. História Social da Criança e da Família. 2. ed. Rio de Janeiro: LTC, 1984.

BARROS, M. de. Memórias Inventadas: a infância. São Paulo: Planeta, 2003.

BARROS, M. de. O livro das Ignorãças. 12. ed. Rio de Janeiro: Record, 2006.

BENJAMIM, W. Reflexões: o brinquedo, a criança, a educação. São Paulo: Summus, 1984a.

BENJAMIN, W. Origem do Drama Barroco Alemão. São Paulo: Brasiliense, 1984b.

BENJAMIM, W. Obras Escolhidas II. 5. ed. São Paulo: Brasiliense, 1995.

GAGNEBIN, J-M. Walter Benjamin: os cacos da história. São Paulo: Brasiliense, 1982. 
GAGNEBIN, J-M. Por que um mundo todo nos detalhes do cotidiano? Revista USP - Dossiê Walter Benjamin, n. 15, p. 44-47, set/out/nov. 1992.

GAGNEBIN, J-M. A criança no limiar do labirinto. In: GAGNEBIN, J-M. História e Narração em Walter Benjamin. 2. ed. revista. São Paulo: Perspectiva, 1999. p. 73-92.

GAGNEBIN, J-M. Mímesis e crítica da representação em Walter Benjamin. In: DUARTE, R.; FIGUEIREDO, V. (Org.). Mímesis e Expressão. Belo Horizonte: UFMG, 2001, p. 353-363.

GAGNEBIN, J-M. Sete Aulas sobre Linguagem, Memória e História. 2. ed. Rio de Janeiro: Imago, 2005.

GOMBRICH, E. H. Meditações sobre um Cavalinho de Pau e Outros Ensaios sobre Teoria da Arte. São Paulo: Editora da USP, 1999, 183p.

HOUAISS, A.; VILLAR, M. de S. Dicionário Houaiss da Língua Portuguesa. 2. reimpressão com alterações. Rio de Janeiro: Objetiva, 2007, 2922p.

JOBIM E SOUZA, S.; PEREIRA, R. M. R. Infância, conhecimento e contemporaneidade. In: KRAMER, S.; LEITE, M. I. (Orgs.). Infância e Produção Cultural. 4. ed. Campinas: Papirus, 2005, p. $25-42$.

LINS, D. Antonin Artaud. 2. ed. Rio de Janeiro: Relume Dumará, 1999, 134p.

MACHADO, F. de A. P. Imanência e História: a crítica do conhecimento em Walter Benjamin. Belo Horizonte: Editora UFMG, 2004, 129p.

MATOS, O. C. F. Desejo de evidência, desejo de vidência: Walter Benjamin. In: NOVAES, A. (Org.). O

Desejo. São Paulo: Companhia das Letras; Rio de Janeiro: Funarte, 1990, p. 283-305.

MATOS, O. O Iluminismo Visionário. São Paulo: Brasiliense, 1993.

MATOS, O. História Viajante: notações filosóficas. São Paulo: Studio Nobel, 1997.

MATOS, O. C. F. A escola de Frankfurt. 2. ed. São Paulo: Moderna, 2005.

RIBEIRO, R. J. O poder de infantilizar. In: GHIRALDELLI JR., P. (Org.). Infância, Escola e Modernidade. São Paulo: Cortez, 1997, p.101-110.

SELIGMANN-SILVA, M. Walter Benjamin: para uma nova ética da memória. Revista Educação Benjamin Pensa a Educação, ano II, p. 48-59, março de 2008.

SOCIEDADE DOS POETAS MORTOS. Direção: Peter Weir. Roteiro: Tom Schulman. Produção:

Steven Haft, Paul Junger, Tony Thomas. EUA: Buena Vista Pictures, 1989. 1DVD (129min.).

TIEDEMANN, R. Introdução à edição alemã (1982). In: BENJAMIN, W. Passagens. Belo Horizonte: Editora da UFMG; São Paulo: Imprensa oficial do estado de São Paulo, 2006, p.13-33.

VAZ, A. F. Marcas do corpo escolarizado, inventário do acúmulo de ruínas. In: OLIVEIRA, M. A. T.

de. (Org.). Educação do Corpo na .... Campinas: Autores Associados, 2006, p.35-56.

WOHLFARTH, I. Terra de ninguém: sobre o “caráter destrutivo” de Walter Benjamin. In: 
BENJAMIN, A.; OSBORNE, P. (Orgs.). A Filosofia de Walter Benjamin: destruição e experiência.

Rio de Janeiro: Jorge Zahar, 1997, p.165-192.

Recebido em: 12 de abril de 2018. Aprovado em: 08 de junho de 2018. 